\title{
Screening for the potential probiotic yeast strains from raw milk to assimilate cholesterol
}

\author{
Li-Shui $\mathrm{CHEN}^{1}$, Ying MA ${ }^{1 *}$, Jean-Louis Maubors ${ }^{2,3}$, Sheng-Hua $\mathrm{HE}^{1}$, \\ Li-Jun $\mathrm{CHEN}^{4}$, Hai-Mei LI ${ }^{1}$ \\ ${ }^{1}$ Harbin Institute of Technology, School of Food Science and Engineering, Harbin 150090, P. R. China \\ ${ }^{2}$ INRA, UMR1253, 65 rue de Saint Brieuc, F-35042 Rennes, France \\ ${ }^{3}$ AGROCAMPUS OUEST, UMR1253, 65 rue de Saint Brieuc, F-35042 Rennes, France \\ ${ }^{4}$ Beijing Sanyuan Foods Co. Ltd., R\&D Center, Beijing 100085, P. R. China
}

Received 11 August 2009 - Revised 8 December 2009 - Accepted 9 December 2009

Published online 18 February 2010

\begin{abstract}
Consumption of dairy products containing probiotics with cholesterol-lowering activity has been proposed as a means to lower serum cholesterol. In the present work, 19 yeast strains, isolated from raw milk, were tested to obtain potential probiotic yeasts for assimilating cholesterol. During in vitro tests, 17 yeast strains were capable of growth in bile salt solutions, and most of the yeast strains tolerated low $\mathrm{pH}$, surviving in gastric juice. Among the 19 strains assessed, Geotrichum sp. BY2 and Pichia kudriavzevii BY10 showed highest adhesive ability to HT-29 cells. All yeast strains were able to assimilate cholesterol in the range of $3.6-44.4 \%$ over a $72 \mathrm{~h}$ incubation, and seven of the yeast strains were significantly higher at assimilating cholesterol $(P<0.05)$. According to these results, the yeast strains P. fermentans BY5, P. kudriavzevii BY10, $P$. kudriavzevii BY15 and Yarrowia lipolytica HY4 may serve as potential probiotics to assimilate cholesterol in the human intestine.
\end{abstract}

yeast / probiotic / raw milk / cholesterol

摘要 - 原料乳中降胆固醇益生酵母菌的篮选。食用含有降胆固醇益生菌的乳制品能降低人 体血清胆固醇。本文研究了 19 株来源于原料乳酵母菌潜在降胆固醇的益生菌特性。体外实 验发现 17 株酵母菌能够在胆盐溶液中生长, 大多数菌株能耐受低 $\mathrm{pH}$ 值, 可以在胃液中存 活。在 19 株菌中, Geotrichum sp. BY2 和 Pichia kudriavzevii BY10 对 HT-29 细胞有最强的 秥附性。培养 $72 \mathrm{~h}$ 后, 所有菌株都能降低胆固醇含量, 范围从 3.6 到 $44.4 \%$ 不等, 其中有 7 株菌明显高于其它菌株 $(P<0.05)$ 。实验结果表明酵母菌 P. fermentans BY5、P. kudriavzevii BY10、P. kudriavzevii BY15 和 Yarrowia lipolytica HY4 能作为潜在降胆固醇的益生菌株进行 深入研究。

\section{酵母 / 益生菌 / 原料乳 / 同化胆固醇}

Résumé - Cribable du potentiel d'assimilation du cholestérol de souches probiotiques de levure isolées à partir de lait cru. La consommation de produits laitiers contenant des probiotiques ayant une activité hypo-cholestérolémiante a été proposée comme moyen d'abaisser le cholestérol sanguin. Dans la présente étude, 19 souches de levure isolées à partir de lait cru ont été testées comme probiotiques potentiels pour assimiler le cholestérol. Au cours des tests in vitro,

*Corresponding author (通讯作者): maying@hit.edu.cn 
17 souches étaient capables de croissance dans des solutions de sels biliaires, et la plupart des souches tolérait bien les faibles $\mathrm{pH}$, en survivant dans le jus gastrique. Parmi les 19 souches testées, Geotrichum sp. BY2 et Pichia kudriavzenii BY10 montraient la plus grande capacité d'adhésion aux cellules HT-29. Toutes les souches de levure étaient capables d'assimiler le cholestérol à hauteur de 3,6 à $44,4 \%$ après une incubation de $72 \mathrm{~h}$ et 7 souches avaient des taux d'assimilation significativement plus élevés $(P<0,05)$. D'après ces résultats, les souches de levure Pichia fermentans BY5, P. kudriavzenii BY10, P. kudriavzenii BY15 et Yarrowia lipolytica HY4 pourraient être utilisées comme probiotiques potentiels pour assimiler le cholestérol au niveau de l'intestin chez l'Homme.

levure / probiotique / lait cru / cholestérol

\section{INTRODUCTION}

Probiotics have been defined as "live microorganisms which when administered in adequate amounts confer a health benefit on the host" [7]. To benefit human health, probiotic microorganisms have been increasingly incorporated into food as dietary adjuncts. The usual microbial inhabitants of the intestinal tracts of human beings and other vertebrates are typically lactobacilli or bifidobacteria [1, 12]. The use of yeasts, as potential probiotics, has also been reviewed $[9,11]$. It is well recognized that yeasts play a significant role in some cheeses and fermented milks [9, 19]. They have the ability to decrease the acidity and facilitate the growth of acido-sensitive bacterial biota by metabolizing lactic acid. In addition, they generate the precursors of aroma compounds, such as free amino acids and free fatty acids, which contribute significantly to the final flavor $[8,26]$. Due to the positive microbial interaction that yeasts have with other species as well as their inhibitory effects against spoilage microorganisms in fermented milk, yeasts are worth studying for use as starter cultures for the development of new dairy products [28].

Several published studies have indicated that some yeast strains isolated from dairy products or human feces have been considered as potential probiotics, as they can survive in the low $\mathrm{pH}$ and bile environment of the gastrointestinal tract $[11,14,20,21]$. It has been reported that Saccharomyces boulardii was effective as a biotherapeutic agent in the prevention or treatment of antibioticassociated diarrhea and human colitis, especially for the treatment of acute diarrhea in children [25]. Recently, many researchers have focused on the antioxidant ability and cholesterol assimilation of yeasts [12, $16,17,21]$. Some reports indicated that yeasts can remove cholesterol in vitro [21]. However, except for S. cerevisiae, Kluyveromyces lactis and Pichia kudriavzevii (former name: Issatchienka orientalis), a limited number of yeasts have been investigated for their ability to assimilate cholesterol [21]. Milk is a suitable growth medium for yeast and some cheeses, such as Cantal cheese in France and Toma Piemontese cheese in Italy, are made from raw milk. Yeast strains, originally isolated from raw milk, impart flavor characteristics and health-promoting properties to the cheese. Therefore, raw milk may be an excellent origin for some probiotic yeasts. The aim of the present work was to identify novel potential probiotic yeasts isolated from raw milk by testing their probiotic potential for assimilating cholesterol.

\section{MATERIALS AND METHODS}

\subsection{Yeast isolates and growth media}

Yeasts were isolated from the raw milk of healthy cattle from various farmhouses in Beijing and Heilongjiang province in China. The somatic cell counts in the raw milk were lower than 500000 . Three samples were 
collected from each region in autumn, winter and summer. All strains were obtained from fresh raw milk or the retentate from a $1.4 \mu \mathrm{m}$ MF membrane (Type MSF 1, Tetra Alcross $^{\circledR}$, Tetra Pak, Denmark) [23]. Strains were identified using an integrated approach that included phenotypic (morphological, biochemical and physiological characterization) and genotypic (RAPD-PCR, sequencing of the D1/D2 domain of $26 \mathrm{~S}$ rDNA encoding gene) methods as well as a commercial API system (API 20C Aux) [3]. The control strain $S$. cerevisiae var. boulardii (CICC1850) was purchased from the China Center of Industrial Culture Collection (CICC).

Yeast strains were cultured at $25{ }^{\circ} \mathrm{C}$ for $24 \mathrm{~h}$ in yeast-peptone-dextrose (YPD) broth containing $0.5 \%(\mathrm{w} / \mathrm{v})$ yeast extract, $1 \%$ peptone and $2 \%$ glucose. YPD agar $(0.5 \%$ $(\mathrm{w} / \mathrm{v})$ yeast extract, $1 \%$ peptone, $0.5 \%$ glucose and $1.8 \%$ agar) was used to maintain the cultures. Prior to the experiment, the cultures were activated for $72 \mathrm{~h}$ at $25^{\circ} \mathrm{C}$ and subcultured at least three times. The total viable cells were adjusted to about $10^{8} \mathrm{cfu} \cdot \mathrm{mL}^{-1}$.

\subsection{Bile tolerance}

Freshly prepared active yeast cells $(1 \% \mathrm{v} / \mathrm{v})$ were added into YPD broth with different concentrations $(0.1 \%, 0.3 \%$ and $0.5 \% \mathrm{w} / \mathrm{v}$ ) of bile salts (Sigma Chemical Co.). The bile tolerance of strains was evaluated based on the decimal increase of yeasts by estimating the number of viable cells after 0 and $72 \mathrm{~h}$ of incubation on YPD agar plates [20]. The bile tolerance was expressed as a percentage $(\%)=$ (increment of cells in broth with bile/increment of cells in broth without bile) $\times 100$.

\subsection{Growth at low $\mathrm{pH}$}

The growth at low $\mathrm{pH}$ was evaluated by inoculating $(1 \% \mathrm{v} / \mathrm{v})$ activated strains into YPD tubes adjusted to $\mathrm{pH} 1.5,2.0,3.0$ and 5.0 with $0.1 \mathrm{~mol} \cdot \mathrm{L}^{-1} \mathrm{HCl}$ and $3 \mathrm{~mol} \cdot \mathrm{L}^{-1} \mathrm{NaOH}$. The tubes were maintained at $37^{\circ} \mathrm{C}$ and growth was determined visually after five days.

\subsection{In vitro survival in gastric juice}

To determine the transit tolerance of yeast strains through simulated gastric juice, the method of Psomas was used with slight modifications [20]. Thirty milliliters of the selected yeast strains were centrifuged at $3000 \times g\left(10 \mathrm{~min}, 4{ }^{\circ} \mathrm{C}\right)$. The cell pellet was washed with sterile phosphate-buffered saline (PBS; $0.1 \mathrm{~mol} \cdot \mathrm{L}^{-1}, \mathrm{pH} 7.2$ ) and $0.8 \%$ $\mathrm{NaCl}$, and re-suspended in the culture at a ratio of $1: 9$. Then, $0.1 \mathrm{~mL}$ of the suspension was added to $1.0 \mathrm{~mL}$ simulated gastric juice that was made up of a solution of pepsin $\left(0.3 \% \mathrm{w} / \mathrm{v} ; 1000 \mathrm{U} \cdot \mathrm{g}^{-1}\right.$, Amresco, USA) and $\mathrm{NaCl}(0.5 \% \mathrm{w} / \mathrm{v})$, to achieve $\mathrm{pH} 1.2$. The yeast cells were enumerated on YPD agar plates after 0 and 90 min of incubation at $37^{\circ} \mathrm{C}$. The results were expressed as the decrease in viability $\%=\left[\left(\mathrm{cfu} \cdot \mathrm{mL}_{0 \mathrm{~h}}^{-1}-\right.\right.$ $\left.\left.\mathrm{cfu} \cdot \mathrm{mL}_{1.5 \mathrm{~h}}^{-1}\right) / \mathrm{cfu} \cdot \mathrm{mL}_{0 \mathrm{~h}}^{-1}\right] \times 100$.

\subsection{Adhesion assay}

The adhesion ability of the strains to human cells was investigated using HT-29 cells that were routinely grown at $37{ }^{\circ} \mathrm{C}$ in a $5 \% \mathrm{CO}_{2}-95 \%$ air atmosphere in PRMI 1640 Medium (Gibco-BRL, USA). L-glutamine with $10 \%$ inactivated $\left(30 \mathrm{~min}, 56^{\circ} \mathrm{C}\right)$ fetal calf serum (FCS, Sigma), $100 \mathrm{U} \cdot \mathrm{mL}^{-1}$ penicillin and $0.1 \mathrm{mg} \cdot \mathrm{mL}^{-1}$ streptomycin was added to the culture. The method of Delgado et al. [6] was used with some modifications. Monolayers of the HT-29 cells were prepared in six-well tissue culture plates (Corning Inco., USA) and then incubated with $\sim 1 \times 10^{7} \mathrm{cfu} \cdot \mathrm{mL}^{-1}$ of the strains to be tested. After $2 \mathrm{~h}$ of incubation at $37{ }^{\circ} \mathrm{C}$ in $5 \% \mathrm{CO}_{2}-95 \%$ air, monolayers were washed four times with sterile PBS, fixed with $10 \%$ formaldehyde solution and stained with Giemsa solution, followed 
by microscopic examination under oil immersion. The number of adherent yeast and HT-29 cells was counted in 20 random microscopic areas. Adhesion capacity of the strains was expressed as the number of yeast cells adhering to 100 HT-29 cells.

\subsection{Assimilation of cholesterol}

Activated yeast cells (1\%) were inoculated in $12 \mathrm{~mL}$ of YPD broth containing $224.2 \mu \mathrm{g} \cdot \mathrm{mL}^{-1}$ of cholesterol (Sigma Chemical Co.) micelles (YPD-CHOL) prepared according to the method of Razin et al. [22]. The mixture was supplemented with $0.3 \%$ bile salt and incubated at $37{ }^{\circ} \mathrm{C}$ for $12-72 \mathrm{~h}$. All experiments were carried out at $37{ }^{\circ} \mathrm{C}$ in order to simulate the temperature of the human gastrointestinal tract. The cells were harvested by centrifugation $\left(12000 \times \mathrm{g}, 15 \mathrm{~min}, 4^{\circ} \mathrm{C}\right.$ ), and $1.0 \mathrm{~mL}$ supernatant fluid was prepared for further analysis of residual cholesterol. Meantime, the pellet was re-suspended in $12 \mathrm{~mL}$ sterile distilled water, and $1.0 \mathrm{~mL}$ of suspension was used to analyze the cholesterol content by GC-MS. To investigate the mechanism of cholesterol assimilation of yeasts, each pellet sample was mixed with $2 \mathrm{~mL}$ distilled water and $0.3 \mathrm{~g}$ acid-washed glass beads $(0.5 \mathrm{~mm}$ diameter $)$. The mixture was then homogenized three times in a bead beater for $30 \mathrm{~s}$ at ambient temperature and maximum speed. The mixture was centrifuged as mentioned above, and the suspension was analyzed.

Cholesterol in the samples was detected according to the method developed by Fletouris et al. [10]. An aliquot $(1.0 \mathrm{~mL})$ of the sample and $5.0 \mathrm{~mL}$ of methanolic $\mathrm{KOH}$ solution $\left(0.5 \mathrm{~mol} \cdot \mathrm{L}^{-1}\right)$ were added into a tightly capped sample tube and vortexed for $15 \mathrm{~s}$, and then kept in an $80^{\circ} \mathrm{C}$ water bath. During heating, the tube was blended for a quick $10 \mathrm{~s}$ every $5 \mathrm{~min}$. After
$15 \mathrm{~min}$, the sample was cooled, and $1 \mathrm{~mL}$ water and $5 \mathrm{~mL}$ hexane were added. The contents were blended vigorously for an additional $1 \mathrm{~min}$. An aliquot of the upper phase was transferred into the autosampler vial and analyzed by a GC/MS system (Model 6890N; Agilent Tech., New York). Analysis was carried out on a gas chromatograph equipped with a flame ionization detector, an automatic sampler (Model AS3000) and a chromatography data system (Model Class-VP). A fused silica capillary column $(30 \mathrm{~m} \times 0.32 \mathrm{~mm}$ i.d. $\times 0.25 \mu \mathrm{m})$ (Hp-413, Hewlett-Packard Company, USA) was used in this work. The oven temperature was set at $285^{\circ} \mathrm{C}$, injection port temperature at $300{ }^{\circ} \mathrm{C}$ and flame ionization detector temperature at $300{ }^{\circ} \mathrm{C}$. The flow rates were $2.0 \mathrm{~mL} \cdot \mathrm{min}^{-1}$ for helium, $30 \mathrm{~mL} \cdot \mathrm{min}^{-1}$ for hydrogen and $300 \mathrm{~mL} \cdot \mathrm{min}^{-1}$ for air. The injection volume was $1 \mu \mathrm{L}$ with a split ratio of 20:1. Mass spectrometer conditions were as follows: interface temperature $220^{\circ} \mathrm{C}$, ion source temperature $200{ }^{\circ} \mathrm{C}$ and quadrupole temperature $100{ }^{\circ} \mathrm{C}$. Acquisition was performed in electron impact mode $(70 \mathrm{eV})$ with 2.0 min solvent delay.

A 7-point calibration curve was generated by injecting $1 \mu \mathrm{L}$ from each working standard solution of cholesterol (purity $>99.5 \%$, Sigma Co.), plotting the recorded peak area versus the corresponding mass of the injected analyte. The content of cholesterol was computed from the standard curve.

\subsection{Statistical analysis}

Data analyses were carried out with SPSS software (version 12.0; SPSS Inc., Chicago, USA). One-way analysis of variance was used to identify significant differences between means, with the significance level at $\alpha=0.05$. Duncan's test was used to perform multiple comparisons between means. All assays were repeated in triplicate. 
Table I. Yeast strains used in this study.

\begin{tabular}{lllc}
\hline Strains & \multicolumn{1}{c}{ Species name } & \multicolumn{1}{c}{ Accession no. } & Base pair $^{1}$ \\
\hline BY1 & Galactomyces sp. & FJ219589 & $2(539)$ \\
BY10 & P. kudriavzevii & FJ219593 & $0(373)$ \\
BY15 & P. kudriavzevii & FJ357144 & $0(573)$ \\
BY31 & P. guilliermondii & FJ219594 & $0(160)$ \\
HY1 & P. guilliermondii & Identical to BY31 & - \\
HY18 & P. guilliermondii & Identical to BY31 & - \\
BY6 & Trichosporon sp. & FJ219592 & $9(585)$ \\
HY4 & Y. lipolytica & FJ357148 & $9(500)$ \\
HY15 & Y. lipolytica & FJ357147 & $3(512)$ \\
HJ6 & Y. lipolytica & FJ219597 & $0(651)$ \\
HJ8 & Y. lipolytica & Identical to HJ6 & - \\
HJ10 & Y. lipolytica & FJ357146 & $4(508)$ \\
BY2 & Geotrichum sp. & FJ219590 & $3(563)$ \\
BY5 & P. fermentans & FJ219591 & $3(561)$ \\
HJ15 & P. fermentans & FJ219598 & $0(529)$ \\
HJ16 & P. fermentans & Identical to HJ15 & - \\
HJ22 & R. mucilaginosa & FJ219600 & $0(371)$ \\
HJ1 & T. gracile & FJ219596 & $4(588)$ \\
HJ2 & T. gracile & Identical to HJ1 & - \\
CICC1850 & S. boulardii & Reference culture & - \\
\hline
\end{tabular}

${ }^{1}$ Number of base pair difference with the corresponding type strain and the overall length of the match are shown in parentheses.

\section{RESULTS AND DISCUSSION}

\subsection{Effects of bile salt on viability}

A set of 19 strains isolated from raw milk from Beijing and Heilongjiang province in China were studied in this work (Tab. I). According to the suggestion of FAO/WHO, it is mandatory to perform a preliminary in vitro assessment before assessing the probiotic properties of bacterial strains [7], such as the capacity for bile tolerance to ensure survival during passage through the gastrointestinal tract $[15,27]$. Regarding the ability of yeasts to withstand bile salts, all yeast strains were incubated in bile salt solutions of $0.1 \%, 0.3 \%$ and $0.5 \%$ for $72 \mathrm{~h}$, respectively. As shown in Table II, the growth of most strains was inhibited by the bile salt solutions, but four strains, P. guilliermondii HY18, Trichosporon gracile HJ2, Geotrichum sp. BY2 and Yarrowia lipolytica HY4, showed good bile resistance, even at a concentration of $0.5 \%$. In the presence of $0.3 \%$ bile, 17 strains showed growth, with the exception of Galactomyces sp. BY1 and T. gracile HJ1. Among the 17 strains, only the growth of T. gracile $\mathrm{HJ} 2$ was not affected by the addition of bile salt as the control.

\subsection{Effects of low pH and gastric juice on the viability}

Another critical factor influencing the viability of microorganisms in the stomach is the presence of gastric acid. The degree of inhibition is related to $\mathrm{pH}$, which can vary widely among individuals. It is an important selection criterion that probiotic 
Table II. Effect of bile salt concentration on the growth of selected yeast strains cultured in YPD at $25^{\circ} \mathrm{C}$ after $72 \mathrm{~h}$ incubation.

\begin{tabular}{|c|c|c|c|}
\hline \multirow[t]{2}{*}{ Strains } & \multicolumn{3}{|c|}{ Increment ${ }^{1}$ in the presence of bile salt $\%(w / v)^{2}$} \\
\hline & 0.1 & 0.3 & 0.5 \\
\hline \multicolumn{4}{|c|}{ Galactomyces sp. } \\
\hline BY1 & - & - & - \\
\hline \multicolumn{4}{|c|}{ Geotrichum sp. } \\
\hline BY2 & $43.9 \pm 1.3$ & $45.0 \pm 3.0$ & $55.3 \pm 4.1$ \\
\hline \multicolumn{4}{|c|}{ P. fermentans } \\
\hline BY5 & $30.9 \pm 2.1$ & $10.3 \pm 1.3$ & $9.5 \pm 2.3$ \\
\hline HJ15 & $56.6 \pm 2.7$ & $79.0 \pm 2.5$ & $9.2 \pm 3.7$ \\
\hline HJ16 & $15.5 \pm 2.3$ & $46.5 \pm 1.6$ & $54.9 \pm 2.4$ \\
\hline \multicolumn{4}{|c|}{ Trichosporon sp. } \\
\hline BY6 & $12.4 \pm 3.6$ & $10.7 \pm 0.6$ & $8.7 \pm 0.4$ \\
\hline \multicolumn{4}{|c|}{ P. kudriavzevii } \\
\hline BY10 & $60.8 \pm 1.2$ & $25.9 \pm 1.2$ & $16.1 \pm 2.5$ \\
\hline BY15 & $41.8 \pm 2.4$ & $21.9 \pm 2.3$ & $18.9 \pm 3.1$ \\
\hline \multicolumn{4}{|c|}{ P. guilliermondii } \\
\hline BY31 & $15.6 \pm 0.3$ & $59.3 \pm 2.6$ & $81.4 \pm 2.7$ \\
\hline HY1 & $24.4 \pm 2.4$ & $35.2 \pm 2.0$ & $21.9 \pm 1.4$ \\
\hline HY18 & $92.8 \pm 1.4$ & $90.5 \pm 5.0$ & 100.0 \\
\hline \multicolumn{4}{|c|}{ R. mucilaginosa } \\
\hline HJ22 & $8.5 \pm 2.6$ & $15.8 \pm 1.8$ & 100.0 \\
\hline \multicolumn{4}{|l|}{ Y. lipolytica } \\
\hline HY4 & $13.7 \pm 2.6$ & $12.7 \pm 1.8$ & $15.9 \pm 1.0$ \\
\hline HY15 & $11.7 \pm 3.8$ & $18.1 \pm 3.3$ & $1.2 \pm 0.4$ \\
\hline HJ6 & $64.6 \pm 2.4$ & $62.9 \pm 2.4$ & $56.6 \pm 1.0$ \\
\hline HJ8 & $15.7 \pm 3.2$ & $36.8 \pm 4.3$ & $43.3 \pm 2.9$ \\
\hline HJ10 & $11.9 \pm 0.2$ & $11.9 \pm 0.8$ & $4.8 \pm 1.3$ \\
\hline \multicolumn{4}{|l|}{ T. gracile } \\
\hline HJ1 & - & - & - \\
\hline $\mathrm{HJ} 2$ & 100.0 & 100.0 & 100.0 \\
\hline \multicolumn{4}{|l|}{ S. boulardii } \\
\hline CICC1850 & 100.0 & 100.0 & 100.0 \\
\hline
\end{tabular}

${ }^{1}$ Bile tolerance $(\%)=$ (increment of cells in broth with bile/increment of cells in broth without bile) $\times 100$; - means cannot tolerate bile; and $100 \%$ means that the growth rate of yeasts is not affected by the added bile salt at all.

${ }_{2}$ All results are expressed as mean \pm standard deviation.

microorganisms can transit the human gastric environment. In this work, the abilities of yeast strains to endure low $\mathrm{pH}(1.5$, 2.0, 3.0 and 5.0) were investigated. All yeast strains survived at $\mathrm{pH} 3.0$ and 5.0 after five days of incubation. However, at $\mathrm{pH} 1.5$ and 2.0 only P. kudriavzevii BY10,
Y. lipolytica HJ6 and Y. lipolytica HY15 displayed viability (data not shown).

It has been reported that the abilities of probiotic bacteria to survive transit through the gastrointestinal tract are variable and strain dependent. The yeast strains displayed variability in surviving in simulated 
Table III. In vitro survival of selected yeast strains at $37{ }^{\circ} \mathrm{C}$ in simulated gastric juice.

\begin{tabular}{|c|c|c|c|}
\hline \multirow[t]{2}{*}{ Strains } & \multicolumn{3}{|c|}{ Viable counts $\left(\log _{10} \mathrm{cfu} \cdot \mathrm{mL}^{-1}\right)^{2}$} \\
\hline & $0 \mathrm{~h}$ & $1.5 \mathrm{~h}$ & Decrease in viability $(\%)^{1}$ \\
\hline \multicolumn{4}{|c|}{ Galactomyces sp. } \\
\hline BY1 & $7.02 \pm 0.03$ & $6.65 \pm 0.07$ & $57.12 \pm 9.30^{\mathrm{ef}}$ \\
\hline \multicolumn{4}{|c|}{ Geotrichum sp. } \\
\hline BY2 & $7.93 \pm 0.04$ & $7.94 \pm 0.03$ & $0.00^{\mathrm{a}}$ \\
\hline \multicolumn{4}{|c|}{ P. fermentans } \\
\hline BY5 & $7.48 \pm 0.01$ & $6.40 \pm 0.03$ & $91.81 \pm 4.67^{\mathrm{ghi}}$ \\
\hline HJ15 & $7.58 \pm 0.03$ & $7.36 \pm 0.05$ & $39.52 \pm 1.44^{\text {cde }}$ \\
\hline HJ16 & $7.56 \pm 0.04$ & $7.27 \pm 0.01$ & $48.56 \pm 1.79^{\mathrm{def}}$ \\
\hline \multicolumn{4}{|c|}{ Trichosporon sp. } \\
\hline BY6 & $7.98 \pm 0.03$ & $7.13 \pm 0.03$ & $85.83 \pm 3.32^{\text {ghi }}$ \\
\hline \multicolumn{4}{|c|}{ P. kudriavzevii } \\
\hline BY10 & $8.27 \pm 0.03$ & $8.36 \pm 0.02$ & $0.00^{\mathrm{a}}$ \\
\hline BY15 & $8.29 \pm 0.01$ & $8.21 \pm 0.02$ & $16.71 \pm 0.30^{\mathrm{b}}$ \\
\hline \multicolumn{4}{|c|}{ P. guilliermondii } \\
\hline BY31 & $8.34 \pm 0.03$ & $8.17 \pm 0.01$ & $35.11 \pm 1.58^{\mathrm{cd}}$ \\
\hline HY1 & $7.88 \pm 0.04$ & $7.00 \pm 0.01$ & $87.12 \pm 1.69^{\mathrm{ghi}}$ \\
\hline HY18 & $7.18 \pm 0.03$ & $6.54 \pm 0.08$ & $76.78 \pm 4.04^{\mathrm{gh}}$ \\
\hline \multicolumn{4}{|c|}{ R. mucilaginosa } \\
\hline HJ22 & $7.30 \pm 0.06$ & $7.10 \pm 0.01$ & $37.03 \pm 1.41^{\mathrm{cd}}$ \\
\hline \multicolumn{4}{|l|}{ Y. lipolytica } \\
\hline HY4 & $8.02 \pm 0.09$ & $7.75 \pm 0.04$ & $46.21 \pm 2.53^{\mathrm{def}}$ \\
\hline HY15 & $8.36 \pm 0.05$ & $7.97 \pm 0.07$ & $59.15 \pm 1.27^{\mathrm{ef}}$ \\
\hline HJ6 & $6.72 \pm 0.09$ & $5.76 \pm 0.01$ & $89.18 \pm 4.48^{\text {ghi }}$ \\
\hline HJ8 & $7.93 \pm 0.04$ & $6.39 \pm 0.12$ & $97.17 \pm 0.35^{\mathrm{i}}$ \\
\hline HJ10 & $7.62 \pm 0.01$ & $7.41 \pm 0.02$ & $36.72 \pm 2.19^{\mathrm{cd}}$ \\
\hline \multicolumn{4}{|l|}{ T. gracile } \\
\hline HJ1 & $7.51 \pm 0.05$ & $6.09 \pm 0.12$ & $96.21 \pm 0.45^{\mathrm{hi}}$ \\
\hline HJ2 & $7.11 \pm 0.05$ & $6.47 \pm 0.16$ & $77.32 \pm 3.27^{\mathrm{g}}$ \\
\hline \multicolumn{4}{|l|}{ S. boulardii } \\
\hline CICC 1850 & $7.44 \pm 0.03$ & $7.32 \pm 0.01$ & $24.12 \pm 5.37^{b}$ \\
\hline
\end{tabular}

${ }^{1}$ Decrease in viability $\%=\left[\left(\mathrm{cfu} \cdot \mathrm{mL}_{0 \mathrm{~h}}^{-1}-\mathrm{cfu} \cdot \mathrm{mL}_{1.5 \mathrm{~h}}^{-1}\right) / \mathrm{cfu} \cdot \mathrm{mL}_{0 \mathrm{~h}}^{-1}\right] \times 100$.

2 All results are expressed as mean \pm standard deviation.

${ }^{\mathrm{a}-\mathrm{i}}$ Means with the same letter within a column are not significantly different $(P>0.05)$.

gastric juice at $\mathrm{pH} 1.2$ (Tab. III). After incubation in the simulated gastric juice for $1.5 \mathrm{~h}$, cell counts of all yeast strains were reduced by $16.7-97.1 \%$ with the exception of Geotrichum sp. BY2 and P. kudriavzevii BY10 which continued to increase in the juice. Under the conditions used in this study, strains P. kudriavzevii BY10 and P. kudriavzevii BY15 (which decreased by
$16.7 \%$ ) exhibited strong resistance to gastric juice, in a manner similar to a strain of $P$. kudriavzevii isolated from infant faces previously reported by Psomas et al. [21]. In comparison to the control strain, there was no significant difference between the control and $P$. kudriavzevii BY15 $(P>0.05)$. Gastric juice resistance of Geotrichum sp. BY2 and P. kudriavzevii BY10 


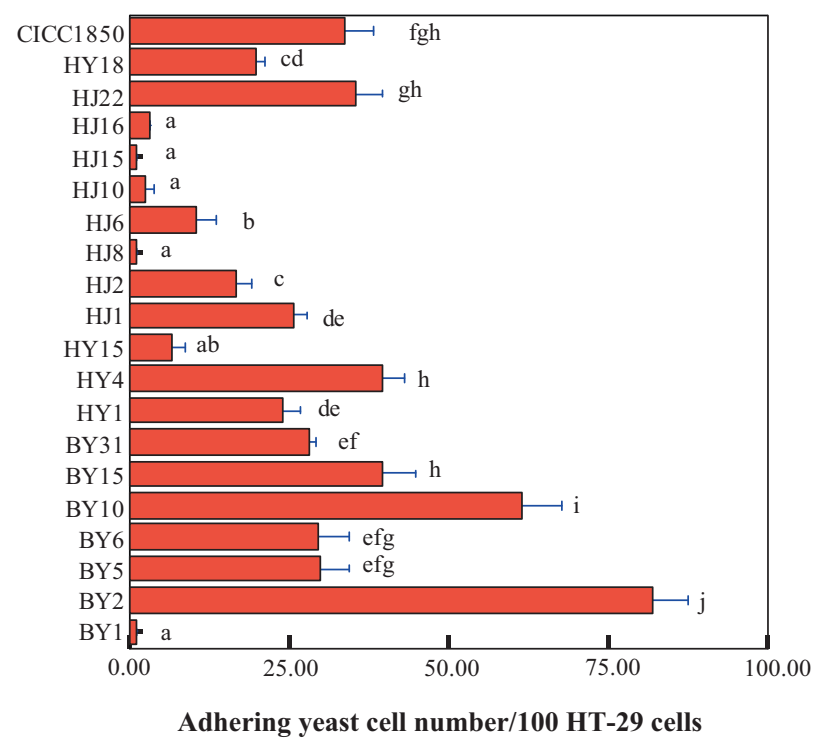

Figure 1. Adhesion to HT-29 cells of yeast strains isolated from raw milk. Number of yeast adhering to the cell monolayer per 100 cells is shown. See Table I for the names of species. CICC1850: the control strain. Standard deviation is shown. ${ }^{\mathrm{a}-\mathrm{j}}$ Values with the same letters are not significantly different $(P<0.05)$.

was significantly higher than the control CICC1850 $(P<0.05)$, while the other isolates were significantly lower than the control $(P<0.05)$.

\subsection{Adhesion ability to HT-29 cells}

Adhesion of probiotic bacteria to the intestinal mucosa is an effective way to exclude pathogens and undesirable bacteria $[2,12]$. Figure 1 shows the number of yeast cells that adhered to 100 HT-29 cells. The adhesion ability of BY2 (80 cells/ 100 HT-29 cells) was highest followed by BY10 (62 cells/100 HT-29 cells) compared to all other strains $(P<0.05)$ tested. The adhesion abilities of both strains were significantly higher than the control (CICC1850) $(P<0.05)$. Strains BY15, HY4, HJ22, BY31, BY5 and BY6 had similar adhesion abilities to the control strain. In contrast to the strains referred to above, the yeasts $P$. guilliermondii $\mathrm{HY} 1$ and $T$. gracile HJ1 showed lower adhesion ability; with the other yeasts, including BY1, HJ10, HJ15 and HJ8, being poorly adhesive to HT-29 cells, at $<5$ cells/100 HT-29 cells. The results indicated that the adhesion ability of yeasts to HT-29 cells was lower than those of bifidobacterium strains (e.g. B. breve ATCC 15698 and $B$. longum BB536) [5]. It may be considered that a single yeast cell is larger than a bacterium cell and hence requires a larger surface with which to adhere to the surface of an intestinal cell than does a bacterium. The adhesive values of HT-29 cells ranging from 2 to 80 were similar to values reported by Kumura et al. [12] regarding yeast adhesion to Caco-2 cells.

To date, there is no selection criterion for the screening of probiotic yeasts for adhesion abilities. However, in vitro experiments have confirmed that the adhesion of 


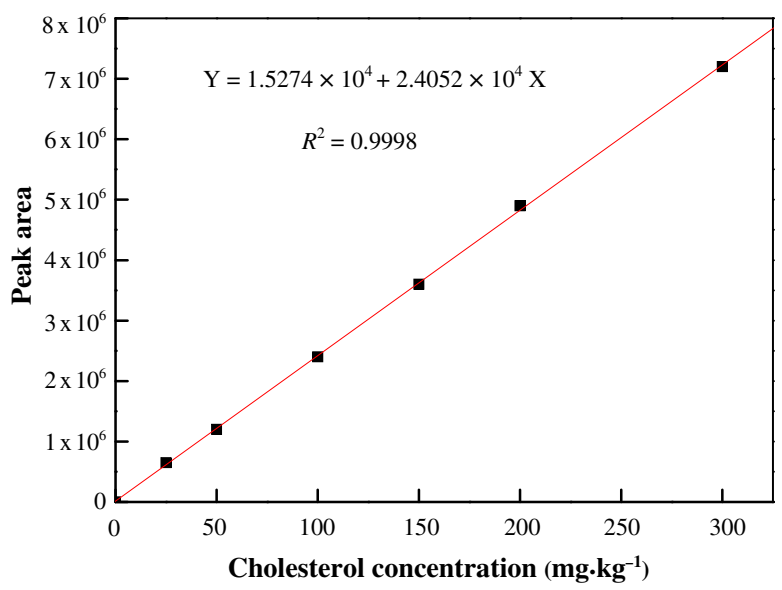

Figure 2. Calibration curve of the cholesterol concentration and peak area.

probiotics can inhibit the adhesion of pathogenic E. coli, Salmonella and other pathogens due to space hindrance [12]. Besides, adhesion is related to the proteins expressed on the surface of the cell walls combined with the cell surface glycolipids of the intestinal bacterial polysaccharide components which are located on the surface of microorganisms and can play an important role in affecting mucosal immune modulation [12]. Furthermore, the doubling time will undoubtedly be extended if a probiotic strain can adhere to the intestinal wall, while nonadhesive microorganisms only remain in the small intestine for several hours [4]. Simply put, the higher the adhesion ability of a strain the greater the chance of protecting the host. Consequently, strains with high adhesive abilities, such as Geotrichum sp. BY2, P. kudriavzevii BY10, P. kudriavzevii $\mathrm{BY} 15$, Rhodotorula mucilaginosa $\mathrm{HJ} 22$ and Y. lipolytica HY4, are the first to be selected as probiotics.

\subsection{Ability to assimilate cholesterol}

High levels of serum cholesterol have been associated with the risk of coronary heart disease, and the use of probiotic bacte- ria to reduce serum cholesterol levels has attracted much attention [13]. S. boulardii, $P$. kudriavzevii and S. cerevisiae have previously been evaluated as potential probiotics for assimilating cholesterol over the past few years [21]. According to the cholesterol concentration standard curve (Fig. 2), the abilities of 19 yeasts to assimilate cholesterol in the presence of bile salts were calculated as shown in Table IV. All yeast strains could assimilate cholesterol from YPDCHOL broth containing bile salt and cholesterol after $72 \mathrm{~h}$ growth at $37{ }^{\circ} \mathrm{C}$. After $12 \mathrm{~h}$, seven yeast strains (BY1, BY2, BY5, BY10, BY15, BY31 and HJ10) had cholesterol assimilation abilities ranging from $2.3 \%$ to $17.5 \%$. After $24 \mathrm{~h}, 10$ strains had cholesterol assimilating abilities that ranged from $6.7 \%$ to $27 \%$. Among the 10 yeast strains, P. kudriavzevii BY10 had the highest cholesterol assimilation ability. After $48 \mathrm{~h}$ incubation, P. kudriavzevii BY15 and P. guilliermondii BY31 displayed the best cholesterol assimilation ability of 44.345.6\%. After $72 \mathrm{~h}$ incubation, seven strains, namely Galactomyces sp. BY1, P. fermentans BY5, P. kudriavzevii BY10, P. kudriavzevii BY15, P. guilliermondii BY31, Y. lipolytica HY4 and Y. lipolytica 
Table IV. Cholesterol assimilation of various yeast strains inoculated in YPD broth, supplemented with bile salt $(0.3 \%)$ and cholesterol $\left(224.2 \mu \mathrm{g} \cdot \mathrm{mL}^{-1}\right)$, and incubated at $37{ }^{\circ} \mathrm{C}$ from 12 to $72 \mathrm{~h}$.

\begin{tabular}{lcccc}
\hline Strains ${ }^{1}$ & \multicolumn{4}{c}{ Cholesterol assimilation $(\%)^{2}$} \\
\cline { 2 - 5 } & $12 \mathrm{~h}$ & $24 \mathrm{~h}$ & $48 \mathrm{~h}$ & $72 \mathrm{~h}$ \\
\hline BY1 & $7.5 \pm 0.8^{\mathrm{de}}$ & $23.1 \pm 1.9^{\mathrm{f}}$ & $36.3 \pm 1.1^{\mathrm{de}}$ & $44.0 \pm 2.4^{\mathrm{d}}$ \\
BY2 & $2.3 \pm 1.6^{\mathrm{b}}$ & $7.0 \pm 0.4^{\mathrm{b}}$ & $16.7 \pm 1.6^{\mathrm{b}}$ & $23.8 \pm 1.5^{\mathrm{c}}$ \\
BY5 & $5.7 \pm 1 .^{\text {cde }}$ & $17.9 \pm 2.0^{\mathrm{e}}$ & $35.6 \pm 1.8^{\mathrm{d}}$ & $40.3 \pm 2.1^{\mathrm{d}}$ \\
BY6 & $0.0^{\mathrm{a}}$ & $6.8 \pm 0.4^{\mathrm{b}}$ & $17.5 \pm 0.3^{\mathrm{b}}$ & $23.5 \pm 2.3^{\mathrm{c}}$ \\
BY10 & $17.5 \pm 1.3^{\mathrm{f}}$ & $27.0 \pm 2.6^{\mathrm{g}}$ & $37.4 \pm 2.8^{\mathrm{f}}$ & $43.2 \pm 1.9^{\mathrm{d}}$ \\
BY15 & $6.2 \pm 0.1^{\mathrm{c}}$ & $13.1 \pm 1.1^{\mathrm{c}}$ & $45.7 \pm 2.6^{\mathrm{g}}$ & $44.4 \pm 3.0^{\mathrm{d}}$ \\
BY31 & $8.7 \pm 0.4^{\mathrm{e}}$ & $13.6 \pm 1.3^{\mathrm{c}}$ & $44.4 \pm 2.4^{\mathrm{g}}$ & $44.4 \pm 2.3^{\mathrm{d}}$ \\
HY1 & $0.0^{\mathrm{a}}$ & $0.0^{\mathrm{a}}$ & $0.0^{\mathrm{a}}$ & $5.6 \pm 0.2^{\mathrm{ab}}$ \\
HY4 & $0.0^{\mathrm{a}}$ & $13.7 \pm 2.1^{\mathrm{c}}$ & $37.4 \pm 1.8^{\mathrm{f}}$ & $39.8 \pm 2.3^{\mathrm{d}}$ \\
HY15 & $0.0^{\mathrm{a}}$ & $0.0^{\mathrm{a}}$ & $0.0^{\mathrm{a}}$ & $7.2 \pm 1.1^{\mathrm{b}}$ \\
HJ1 & $0.0^{\mathrm{a}}$ & $0.0^{\mathrm{a}}$ & $0.0^{\mathrm{a}}$ & $6.5 \pm 0.2^{\mathrm{ab}}$ \\
HJ8 & $0.0^{\mathrm{a}}$ & $0.0^{\mathrm{a}}$ & $0.0^{\mathrm{a}}$ & $3.6 \pm 0.3^{\mathrm{a}}$ \\
HJ2 & $0.0^{\mathrm{a}}$ & $0.0^{\mathrm{a}}$ & $0.0^{\mathrm{a}}$ & $6.2 \pm 0.5^{\mathrm{ab}}$ \\
HJ6 & $0.0^{\mathrm{a}}$ & $0.0^{\mathrm{a}}$ & $0.0^{\mathrm{a}}$ & $5.5 \pm 0.4^{\mathrm{ab}}$ \\
HJ10 & $22.3 \pm 1.6^{\mathrm{f}}$ & $30.9 \pm 1.1^{\mathrm{c}}$ & $45.5 \pm 2.3^{\mathrm{d}}$ \\
HJ15 & $0.0^{\mathrm{a}}$ & $0.0^{\mathrm{a}}$ & $4.6 \pm 0.3^{\mathrm{ab}}$ \\
HJ16 & $0.0^{\mathrm{a}}$ & $0.0^{\mathrm{a}}$ & $0.0^{\mathrm{a}}$ & $6.8 \pm 1.1^{\mathrm{ab}}$ \\
HJ22 & $0.0^{\mathrm{a}}$ & $0.0^{\mathrm{a}}$ & $0.0^{\mathrm{a}}$ & $5.4 \pm 0.4^{\mathrm{ab}}$ \\
HY18 & $0.0^{\mathrm{a}}$ & $0.0^{\mathrm{a}}$ & $0.0^{\mathrm{a}}$ & $3.7 \pm 0.2^{\mathrm{ab}}$ \\
CICC1850 & $0.0^{\mathrm{a}}$ & $16.8 \pm 2.1^{\mathrm{d}}$ & $36.5 \pm 1.4^{\mathrm{e}}$ & $41.5 \pm 2.3^{\mathrm{d}}$ \\
\hline
\end{tabular}

${ }^{1}$ The names of species are given in Table I.

${ }^{2}$ Results are expressed as mean \pm standard deviation.

${ }^{\mathrm{a}-\mathrm{g}}$ Means within a column with the same letter are not significantly different $(P>0.05)$.

HJ10, showed high cholesterol assimilation abilities ranging from $39.8 \%$ to $45.5 \%$, which were not significantly different $(P>0.05)$ than the control.

In vitro, significant differences were detected between yeast strains and incubation time $(P<0.05)$ for the cholesterol assimilation ability. In particular, a significant correlation was detected between the assimilation ability and the incubation time at $\alpha=0.01$ level $\left(R^{2}=0.458\right)$. Due to their strain specificity, P. kudriavzevii BY10 and P. kudriavzevii BY15 showed lower cholesterol assimilating abilities (43.2\% and 44.4\%) after $72 \mathrm{~h}$ incubation compared to that of P. kudriavzevii KK5.Y.1 (93.6\%) reported by Psomas et al. [21]. However, strains $P$. $k u$ driavzevii BY5 and P. kudriavzevii BY15 were capable of assimilating cholesterol after $12 \mathrm{~h}$ incubation in contrast to KK5.Y.1.

For lactobacilli, three possible mechanisms for the assimilation of cholesterol from media are proposed: assimilation of cholesterol during growth, incorporation of cholesterol into the membranes of the cells and binding cholesterol to the cell's surface [13]. In the present study, the mechanism of cholesterol reduction during growth was investigated using mass spectroscopy to detect the product formed by the metabolism of cholesterol by yeasts during growth. No metabolic products other than cholesterol were detected in the re-suspension, and only a little cholesterol was found in pellets homogenized in a bead beater (data not shown). Thus, the cholesterol removed 
by the yeast strains tested was considered not to be metabolically degraded but absorbed by the growing yeast cells. This might be attributed to cell wall lysis by lysozymes [21]. As a result, yeast cells inhibit the absorption of cholesterol by the body.

It is well known that significant numbers of cells need to survive and grow in the bile of the human intestinal tract to influence the microbial balance of the intestine. As a result, Galactomyces sp. BY1 is not suitable to be used as a probiotic due to its poor tolerance to bile. Y. lipolytica HJ10 could not be chosen as a potential probiotic because of its low adhesion ability, although it has similar cholesterol assimilation ability as the control. In addition, $P$. guilliermondii has rarely been reported for use in the fermented milk products. Considering food safety, P. guilliermondii BY31 is not suitable for use in the dairy industry as a probiotic strain, even though it had good cholesterol assimilation ability. From the above-mentioned results, $P$. kudriavzevii BY10 and P. kudriavzevii BY15 are considered as ideal probiotic candidates. They have been isolated from human infant feces [21] and from cheese [24] which will accelerate their promising use as probiotics. Also, $P$. fermentans and $Y$. lipolytica have also been frequently isolated from cheese and kefir $[18,24]$. Therefore, $P$. fermentans BY5 and Y. lipolytica HY4 could also be considered as potential probiotic yeasts for their good cholesterol assimilation ability, adhesive ability and better survival in simulated gastric acid.

\section{CONCLUSIONS}

Based on the tolerance to bile salt, survival under low $\mathrm{pH}$ and gastric juice and the assimilation of cholesterol, four yeast strains ( $P$. fermentans BY5, P. kudriavzevii BY10, P. kudriavzevii BY15 and Y. lipolytica HY4) were selected as potential probiotics to assimilate cholesterol in the human intestine.

\section{REFERENCES}

[1] Belviso S., Giordano M., Dolci P., Zeppa G., In vitro cholesterol-lowering activity of Lactobacillus plantarum and Lactobacillus paracasei strains isolated from the Italian Castelmagno PDO cheese, Dairy Sci. Technol. 89 (2009) 169-176.

[2] Blum S., Reniero R., Schiffrin E.J., Crittenden R., Mattila-Sandholm T., Ouwehand A.C., Salminen S., von Wright A., Saarela M., Saxelin M., Collins K., Morelli L., Adhesion studies for probiotics: need for validation and refinement, Trends Food Sci. Technol. 10 (1999) 405-410.

[3] Chen L.-S., Ma Y., Maubois J.-L., Chen L.-J., Liu Q.-H., Guo J.-P., Identification of yeasts from raw milk and selection for some specific antioxidant properties, Int. J. Dairy Technol. 63 (2010) 47-54.

[4] Conway P.L., Gorbach S.L., Goldin B.R., Survival of lactic acid bacteria in the human stomach and adhesion to intestinal cells, J. Dairy Sci. 70 (1987) 1-12.

[5] Crociani J., Grill J.-P., Huppert M., Ballongue J., Adhesion of different bifidobacteria strains to human enterocyte-like Caco-2 cells and comparison with in vivo study, Lett. Appl. Microbiol. 21 (1995) 146-148.

[6] Delgado S., Sullivan E.O., Fitzgerald G., Mayo B., In vitro evaluation of the probiotic properties of human intestinal bifidobacterium species and selection of new probiotic candidates, J. Appl. Microbiol. 104 (2008) 1119-1127.

[7] FAO/WHO, Guidelines for the evaluation of probiotics in food, London, Ontario, Canada, 2002.

[8] Ferreira A.D., Viljoen B.C., Yeasts as adjunct starters in matured cheddar cheese, Int. J. Food Microbiol. 86 (2003) 131-140.

[9] Fleet G.H., A review: yeasts in dairy products, J. Appl. Bacteriol. 68 (1990) 199-211.

[10] Fletouris D.J., Botsoglou N.A., Psomas I.E., Mantis A.I., Rapid determination of cholesterol in milk and milk products by direct saponification and capillary gas chromatography, J. Dairy Sci. 81 (1998) 2833-2840.

[11] Jakobsen M., Narvhus J., Yeasts and their possible beneficial and negative effects on the quality of dairy products, Int. Dairy J. 6 (1996) 755-768. 
[12] Kumura H., Tanoue Y., Tsukahara M., Tanaka T., Shimazaki K., Screening of dairy yeast strains for probiotic applications, J. Dairy Sci. 87 (2004) 4050-4056.

[13] Liong M.T., Shah N.P., Acid and bile tolerance and cholesterol removal ability of lactobacilli strains, J. Dairy Sci. 88 (2005) 55-66.

[14] Lourens-Hattingh A., Viljoen B.C., Growth and survival of a probiotic yeast in dairy products, Food Res. Int. 34 (2001) 791-796.

[15] Mishra V., Prasad D.N., Application of in vitro methods for selection of Lactobacillus casei strains as potential probiotics, Int. J. Food Microbiol. 103 (2005) 109-115.

[16] Naylin N., Suganuma T., Taing O., Antioxidant activities of compounds isolated from fermented broth of Zygosaccharomyces rouxii, Food Biotechnol. 20 (2006) 131-141.

[17] Naylin N., Taing O., Hashinaga F., Toshima Y., Antioxidant activity of sugar-tolerant yeast Zygosaccharomyces rouxii, Food Biotechnol. 19 (2005) 107-120.

[18] Nunez M., Margarita M., Pilar G., Carmen D.-A., Les levures et les moisissures dans le fromage bleu de Cabrales, Lait 61 (1981) 62-79.

[19] Pereira-Dias S., Potes M.E., Marinho A., Malfeito-Ferreira M., Loureiro V., Characterisation of yeast flora isolated from an artisanal Portuguese ewes' cheese, Int. J. Food Microbiol. 60 (2000) 55-63.

[20] Psomas E.I., Andrighetto C., LitopoulouTzanetaki E., Lombardi A., Tzanetakis N., Some probiotic properties of yeast isolates from infant faeces and Feta cheese, Int. J. Food Microbiol. 69 (2001) 125-133.
[21] Psomas E.I., Fletouris D.J., LitopoulouTzanetaki E., Tzanetakis N., Assimilation of cholesterol by yeast strains isolated from infant feces and Feta cheese, J. Dairy Sci. 86 (2003) 3416-3422.

[22] Razin S., Kutner S., Efrati H., Rottem S., Phospholipid and cholesterol uptake by mycoplasma cells and membranes, Biochim. Biophys. Acta 598 (1980) 628-640.

[23] Saboya L.V., Maubois J.-L., Current developments of microfiltration technology in the dairy industry, Lait 80 (2000) 541-553.

[24] Tornadijo M.E., Fresno J.M., Sarmiento R.M., Carballo J., Study of the yeasts during the ripening process of Armada cheeses from raw goat's milk, Lait 78 (1998) 647-659.

[25] van der Aa Kühle A., Skovgaard K., Jespersen L., In vitro screening of probiotic properties of Saccharomyces cerevisiae var. boulardii and food-borne Saccharomyces cerevisiae strains, Int. J. Food Microbiol. 101 (2005) 29-39.

[26] Vasdinyei R., Deák T., Characterization of yeast isolates originating from Hungarian dairy products using traditional and molecular identification techniques, Int. J. Food Microbiol. 86 (2003) 123-130.

[27] Vinderola G., Capellini B., Villarreal F., Suárez V., Quiberoni A., Reinheimer J., Usefulness of a set of simple in vitro tests for the screening and identification of probiotic candidate strains for dairy use, LWT - Food Sci. Technol. 41 (2008) 1678-1688.

[28] Wouters J.T.M., Ayad E.H.E., Hugenholtz J., Smit G., Microbes from raw milk for fermented dairy products, Int. Dairy J. 12 (2002) 91-109. 